\title{
BISOPROLOL VERSUS ENALAPRIL ON HEMODYNAMICS UNDER GENERAL ANESTHESIA
}

\author{
By
}

\author{
Tawfik M. Noor El-Din, Saad Aldin M. Alkhateeb, Abdallah M. Ahmed, \\ Yosry M. Abdel Salam* and Ayman H. Mahmoud* \\ Departments of Anesthesia and Intensive Care, Faculty of Medicine, Al-Azhar University \\ (Cairo and Damietta*) \\ *Corresponding author details: draymanalsettieny@gmail.com
}

\begin{abstract}
Background: Systemic arterial hypertension is a common disease in patients undergoing surgery. Bisoprolol and Enalapril are anti-hypertensive drugs that affect the perioperative hemodynamics (blood pressure and pulse rate) in different manners.

Objectives: The aim of the present study was to compare the effect of general anesthesia on the hemodynamics of hypertensive patients undergoing elective surgery and controlled on Enalapril versus Bisoprolol as a primary outcome, and criteria of discharge from recovery room, postoperative pain assessment, and adverse effects as a secondary outcome.

Patients and Methods: In this comparative clinical randomized study, thirty hypertensive patients of both sexes, aged from 40 to 60 years, according to the American Society of Anesthiologists (ASA) physical status class II, undergoing elective surgery under general anesthesia of less than two hours duration (Abdominal and upper limb surgery), and controlled on antihypertensive medication regularly administered for at least six months duration (Enalapril versus Bisoprolol) were enrolled in the study. The study started from January, 2016 to February, 2018. Patients were randomly allocated into equal two groups, group (A) hypertensive patients controlled on Enalapril $10 \mathrm{mg}$ and group (B) hypertensive patients controlled on Bisoprolol $5 \mathrm{mg}$. To evaluate intraoperative arterial blood pressure:( systolic arterial blood pressure, diastolic arterial blood pressure and mean arterial blood pressure) and Heart rate as follow: preoperative basal arterial blood pressure and pulse rate reading (0), immediately after induction, (1), every 5 minutes for 20 minutes and every 15 minutes till the end of the operation.
\end{abstract}

Results: Hypertensive patients controlled on Enalapril (group E) had more statistically significant decrease in blood pressure (systolic-diastolic-mean) after induction of general anesthesia and more hypotensive episodes in the first 30 minutes after induction than patients treated with Bisoprolol $5 \mathrm{mg}$ (group B) while, group A had more increase in blood pressure post-intubation, post-extubation and on exposure to noxious stimuli .

When comparing heart rate changes between both studied groups the results showed that hypertensive patients controlled on Bisoprolol (group B) had more statistically significant heart rate control (decrease) all over the operation especially at periods of intraoperative stress as post-intubation, 1st 30 minutes of operation and post extubation than hypertensive patients controlled on Enalapril (group A).

The remaining intraoperative periods of the operation are nearly comparable between both studied groups ( $A$ and $\mathrm{B}$ ) as regard blood pressure and heart rate.

Patients of both groups (A and B) had no statistically significant difference as regard criteria of discharge from recovery room, postoperative pain assessment and adverse effects. 
Conclusion: Bisoprolol as a beta blocking antihypertensive drug was associated with effective control of pulse rate and blood pressure and attenuation of pressor response to all stressful events all over the operation especially after laryngoscopy, intubation, extubation and the first 30 minutes of operation ensuring more hemodynamic stability under general anesthesia when compared to hypertensive patients controlled on Enalapril.

Recommendation: Beta blockers (Bisoprolol) are recommended before surgery even for those who do not use them when exposed to anesthesia unless there are contraindications.

Key words: Enalapril, Bisoprolol, hemodynamics, general anesthesia.

\section{INTRODUCTION}

Hypertension (HTN) affects one billion individuals worldwide, particularly the elderly, and represents a major risk factor for coronary artery disease, heart failure, and renal and cerebrovascular disease. Elevated blood pressure is the most frequent preoperative health problem in non-cardiac surgery patients, with an overall prevalence of $20-25 \%$ (Athanasios et al., 2010).

Intraoperative acute blood pressure elevations of over $20 \%$ during surgery are considered a hypertensive emergency, and chronic hypertensive patients are more likely to have labile hemodynamics during a procedure (Soto-Ruiz et al., 2011).

Chronic hypertension, even isolated, still increases the risk of cardiovascular incidents during anaesthesia by $40 \%$. Although the guidelines do not consider isolated hypertension as a significant cause of peri-operative cardiovascular morbidity, the anaesthetic management of hypertensive patients must place particular emphasis on maintaining intra-operative hemodynamic stability (Beyer et al., 2009).

ACEIs have become a mainstay of antihypertensive therapy. In addition to lowering blood pressure, there is overwhelming evidence that ACEIs (and angiotensin receptor blockers) provide end-organ protection independent of their blood pressure-lowering properties in diseases such as congestive heart failure, post- myocardial infarction (MI), diabetes mellitus, and renal insufficiency (Barodka et al., 2012).

Beta blockers remain appropriate treatments for hypertensive patients with concomitant ischemic heart disease, angina pectoris, post-myocardial infarction, left ventricular dysfunction with heart failure, obstructive cardiomyopathy, arrhythmias, aortic dissection, and hyperkinetic circulations (tachycardia, palpitations, hypertension, and anxiety (Frishman and Saunders, 2011).

The present work aimed to study the effect of general anesthesia on the hemodynamics of hypertensive patients undergoing elective surgery, and controlled on Enalapril versus Bisoprolol as a primary outcome, and criteria of discharge from recovery room, postoperative pain assessment, and adverse effects as a secondary outcome.

\section{PATIENTS AND METHODS}

This comparative clinical randomized study was carried out at Al-Azhar University hospital (Damietta) from January 2016 to February 2018. The study was carried out after local ethics committee approval and written informed 
consent from thirty hypertensive patients of both sexes, aged from 40 to 60 years, uncomplicated, and admitted to Al-Azhar University Hospitals scheduled for elective surgery under general anesthesia of less than two hours duration. Patients were selected according to the American Society of Anesthiologists (ASA) physical status class II, and controlled on single antihypertensive medication regularly administered for at least six months duration (Enalapril versus Bisoprolol).

All patients who have treated by combined therapy, discontinued the antihypertensive drugs during the last 6 months till the time of the surgical operation, uncontrolled hypertension on medical treatment, associated with complications of hypertension (target organ damage) or severe systemic illness as severe hepatic, cardiac, renal and respiratory illness were excluded from the study.

Patients were randomly classified and completely separated using closed envelope method into two equal groups, fifteen patients each: group (A) hypertensive patients daily controlled on Enalapril $10 \mathrm{mg}$ and group (B) hypertensive patients daily controlled on Bisoprolol $5 \mathrm{mg}$.

1ry outcome: Evaluation of intraoperative hemodynamics of hypertensive patient controlled on Enalapril versus Bisoprolol when exposed to general Anesthesia.

2ry outcome: Criteria of discharge from recovery room, postoperative pain assessment adverse effect.

Every patient was subjected to a careful complete pre-anesthesia assessment; including preoperative history evaluation, physical examination and investigations, complete blood picture, random blood glucose, blood urea, serum creatinine, SGOT, SGPT, prothrombin time, INR, electrocardiogram, echocardiography (to detect early complications as left ventricular hypertrophy, ischemia or valve diseases), and chest X-ray.

In the operating room, an intravenous cannula $(20 \mathrm{G})$ was inserted, and patients received fluids (500 $\mathrm{ml}$ of normal saline). All patients received preoperative antihypertensive agents as close to schedule as possible, and premedicated by an anxiolytic agent, midazolam which was given to every patient at dose of (0.5 to 2.5mg IV) 15-30 minutes preoperatively.

\section{Adequate monitoring was instituted prior to induction of anesthesia including:}

1. Pulse oximeter for continuous recording of pulse rate and oxygen saturation.

2. Non-invasive blood pressure every 5 minutes.

3. Lead II electrocardiography (5 lead ECG).

4. Capnography for ETCO2 to be adjusted between $30-35 \mathrm{mmHg}$ using (A NIHON KOHDEN monitor).

5. Continuous airway pressures monitoring during controlled ventilation.

Baseline pulse rate, blood pressure and respiratory rate recorded before general anesthesia. General anesthesia was conducted after 5 minutes preoxygenation by a face mask with $100 \%$ O2 applied by Magill breathing system using the 
following agents before endotracheal intubation:

$$
\text { 1. Propofol (2 } \mathrm{mg} / \mathrm{kg} / \mathrm{dose})
$$
intravenously.

2. Administering Lidocaine $1.5 \mathrm{mg} / \mathrm{kg}$ intravenously.

3. Administering a bolus of Fentanyl, ( $2 \mathrm{mcg} / \mathrm{kg} / \mathrm{dose})$.

4. Administering a bolus of Rocuronium, (0.6 mg/kg/dose) as a loading dose as soon as the eyelid reflex is lost to facilitate endotracheal intubation.

5. Deepening anesthesia with Isoflurane (MAC 1.2) for 5-10 min.

Endotracheal intubation was performed and patient was connected to anesthesia machine Dragger Fabius 4 Plus, and mechanically ventilated using VCV (volume-controlled ventilation) mode.

General anesthesia was maintained using Isoflurane (MAC 1.2) and Fentanyl boluses $(50 \mathrm{mcg} / \mathrm{dose})$ if needed together with a maintenance dose of rocuronium $(0.2 \mathrm{mg} / \mathrm{kg} \mathrm{IV})$ every 45 minutes or PRN as a muscle relaxant. Blood loss was also monitored carefully, and deficits replaced promptly by IV fluids or blood accordingly to avoid hypovolemia. Small doses of ephedrine (5-10 mg) were given when vagal tone was high.

\section{Assessment in operating room}

The patient was assessed in the operating room for arterial blood pressure (systolic arterial blood pressure, diastolic arterial blood pressure and mean arterial blood pressure) and heart rate, preoperative basal readings, immediately after induction, every 5 minutes for 20 minutes, and every 15 minutes till the end of the operation.

Hypertension was considered when there was an increase of more than $20 \%$ of the basal reading of arterial blood pressure. Hypotension was considered when there was a drop of $20 \%$ of the basal reading of arterial blood pressure which was treated by increasing the rate of infusion of IV fluids and the administration of $5 \mathrm{mg}$ increments of ephedrine.

Tachycardia was considered when pulse rate was >100 bpm. Bradycardia was considered when pulse rate was $<60$ bpm and was treated with IV $0.5 \mathrm{mg}$ atropine.

After discontinuing the anesthetic agents, giving the reversal of neuromuscular blockade agent, neostigmine (0.03-0.07 mg/kg IV) and atropine $\quad(0.01-0.02 \mathrm{mg} / \mathrm{kg})$. Tracheal extubation was done, $100 \%$ O2 was given, airway of the patient was supported until respiratory reflexes were intact.

All patients were assessed in the recovery area (Phase 1) at 15-minute intervals with the Mayo Modified Discharge Scoring System. A Mayo Modified Discharge Scoring System of 8 or higher was noted and was taken as a time that could be used as an index of fitness to move from a primary recovery area to a secondary area (Jankowski et al., 2003).

In the phase 2 recovery area (Hospital Word), patients were assessed every 1 hour. Once they had achieved a score of 9 points on the postanesthetic discharge scoring system (PADSS), they were 
deemed fit for discharge (Chung et al., 1997).

Postoperatively, pain was assessed at rest with a $10-\mathrm{cm}$ visual analog scale (VAS) until hospital discharge. In the phase 1 recovery area, nothing given if VAS score $\leq 4 \mathrm{~mm}$. Morphine sulfate 2.5 mg was administered by IV injection until the patient was comfortable (VAS score $>4 \mathrm{~mm}$ ) (Brokelman et al, 2012).

The pain management protocol in phase 2 and at home consisted of $400 \mathrm{mg}$ of oral ibuprofen every 8 hours and rescue analgesia with oral acetaminophen (one g) if the patient asked for more analgesic. When patients were discharged from the hospital, they were asked to rate their pain intensity at rest on the VAS initially every 1 hour for 2 hours, then every 2 hours for the next 6 hours then at $6,12,18$, and 24 hours after surgery and record their analgesic consumption.
Statistical Analysis: The collected data were organized, tabulated and statistically analyzed using Microsoft office excel (2016) (Microsoft ${ }^{\circledR}$ Inc., USA) and statistical package for social sciences (SPSS) version 22 (SPSS Inc., Chicago, USA), running on DELL compatible computer. For qualitative data, frequency and percent distributions were calculated. For quantitative data, mean, standard deviation (SD), minimum and maximum were calculated. For comparison between two groups, the independent samples $(\mathrm{t})$ test was used. Pearson correlation coefficient (r-test) was used for correlating different variables. For all tests $\mathrm{p}$ value $<0.05$ were considered significant. For all tests $\mathrm{p}$ value $>0.05$ were considered insignificant.

\section{RESULTS}

I. Demographic data: there were no significant differences between the studied groups as regard to age, sex, BMI, type and duration of surgery (Table 1).

Table (1): Demographic data (mean \pm SD or number \%) in studied populations

\begin{tabular}{|c|c|c|c|c|}
\hline Paramete & Groups & $A(N=15)$ & $B(N=15)$ & P-value \\
\hline \multicolumn{2}{|c|}{ Age (yr) } & $49.73 \pm 1.41$ & $50.67 \pm 1.27$ & $>0.05$ \\
\hline \multirow{2}{*}{ Sex } & Male & $13(86.6 \%)$ & $14(93.4 \%)$ & \multirow{2}{*}{$>0.05$} \\
\hline & Female & $2-(13.4 \%)$ & $1(6.6 \%)$ & \\
\hline \multicolumn{2}{|c|}{ BMI $\left(\mathrm{kg} / \mathrm{m}^{2}\right)$} & $27.68 \pm 1.72$ & $27.78 \pm 1.57$ & $>0.05$ \\
\hline \multirow{2}{*}{ 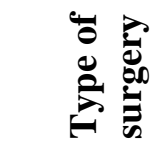 } & Abdominal & $10(66.6 \%)$ & $9(60 \%)$ & \multirow[b]{2}{*}{0.05} \\
\hline & Upper limb & $5(33.4 \%)$ & $6(40 \%)$ & \\
\hline \multicolumn{2}{|c|}{ Duration of surgery } & $78.6 \pm 2.37$ & $74.0 \pm 2.21$ & $>0.05$ \\
\hline
\end{tabular}




\section{Hemodynamic parameters:}

- Systolic arterial blood pressure: There was statistically significant decrease in systolic blood pressure immediately after induction of general anesthesia in both groups (A and B) with more decrease in group A than group B. Also, there is statistically significant increase at 5 minutes (post-intubation) in both studied groups with more increase in group $\mathrm{A}$ than group $\mathrm{B}$ and at 80 minutes (postextubation) in group A only when compared with group B. Also, there was statistically significant decrease in group A when compared with group B at $10 \mathrm{~m}$, $15 \mathrm{~m}, 20 \mathrm{~m}, 35 \mathrm{~m}$ after endo-tracheal intubation (Table 2).

Table (2): Systolic blood pressure among studied populations at different points of time

\begin{tabular}{|c|c|c|c|}
\hline \multirow{2}{*}{ Parameters Groups } & A & B & \multirow{2}{*}{ P value } \\
\cline { 2 - 3 } & Mean \pm SD $(\mathbf{m m H g})$ & Mean \pm SD $(\mathbf{m m H g})$ & \\
\hline 0 & $129.6 \pm 2.1$ & $131.07 \pm 2.01$ & $>0.05$ \\
\hline At 5 min (Post-intubation) & $87.4 \pm 1.2$ & $102.27 \pm 1.66$ & $<0.001$ \\
\hline At 10 min & $113.06 \pm 6.91$ & $107.80 \pm 3.69$ & $>0.02$ \\
\hline At 15 min & $104.93 \pm 5.92$ & $109.80 \pm 6.56$ & $<0.04$ \\
\hline At 20 min & $108.40 \pm 4.64$ & $112.33 \pm 3.04$ & $<0.02$ \\
\hline At 35 min & $115.80 \pm 6.04$ & $125.53 \pm 6.59$ & $<0.001$ \\
\hline At 50 min & $119.27 \pm 6.64$ & $123.60 \pm 4.78$ & $<0.05$ \\
\hline At 65 min & $121.33 \pm 7.10$ & $123.27 \pm 7.46$ & $>0.05$ \\
\hline At 80 min (Post-extubation) & $117.87 \pm 5.59$ & $121.40 \pm 7.18$ & $>0.05$ \\
\hline & $132.4 \pm 4.9$ & $122.6 \pm 3.21$ & $<0.001$ \\
\hline
\end{tabular}

- Diastolic arterial blood pressure: There was a statistically significant decrease immediately after induction of general anesthesia in both groups (A and B) with more decrease in group A than group B. Also, there was a statistically significant increase at 5 minutes (postintubation) in both studied groups with more increase in group A than group B and at 80 minutes (post-extubation) in group A only when compared with group B (Table 3).

Table (3): Diastolic blood pressure among studied populations at different points of time

\begin{tabular}{|c|c|c|c|}
\hline \multirow{2}{*}{ Group } & A & B & \multirow{2}{*}{ P value } \\
\cline { 2 - 3 } & Mean \pm SD $(\mathbf{m m H g})$ & Mean \pm SD $(\mathbf{m m H g})$ & \\
\hline 0 & $77.87 \pm 2.78$ & $78.67 \pm 2.87$ & $>0.05$ \\
\hline At 5 min (Post-intubation) & $51.5 \pm 2.2$ & $62.67 \pm 1.75$ & 0.001 \\
\hline At 10 min & $71.00 \pm 3.05$ & $67.13 \pm 4.39$ & $<0.01$ \\
\hline At 15 min & $66.73 \pm 3.97$ & $74.60 \pm 2.85$ & $>0.05$ \\
\hline At 20 min & $65.07 \pm 3.67$ & $73.87 \pm 3.68$ & $>0.05$ \\
\hline At 35 min & $70.07 \pm 4.87 .86$ & $72.53 \pm 4.44$ & $>0.05$ \\
\hline At 50 min & $74.40 \pm 4.70$ & $70.07 \pm 4.86$ & $>0.05$ \\
\hline At 65 min & $76.33 \pm 4.89$ & $76.13 \pm 5.73$ & $>0.05$ \\
\hline At 80 min (Post-extubation) & $83.33 \pm 3.06$ & $77.73 \pm 6.15$ & $>0.05$ \\
\hline
\end{tabular}


- Mean arterial blood pressure: There was a statistically significant decrease immediately after induction of general anesthesia in both groups (A and B) with more decrease in group A than group B. Also, there was a statistically significant increase at 5 minutes (post-intubation) in both studied groups with more increase in group A than group B and at 80 minutes (post-extubation) in group A only when compared with group B. Also, there was a statistically significant decrease in group A when compared with group B at $10 \mathrm{~m}$, $15 \mathrm{~m}, 20 \mathrm{~m}$, after endo-tracheal intubation (Table 4).

Table (4): Mean arterial blood pressure among studied populations at different points of time

\begin{tabular}{|c|c|c|c|}
\hline \multirow{2}{*}{ Parameters Groups } & A & B & \multirow{2}{*}{ P value } \\
\cline { 2 - 4 } & Mean \pm SD $(\mathbf{m m H g})$ & Mean \pm SD $(\mathbf{m m H g})$ & \\
\hline 0 & $94.9 \pm 2.4$ & $96.07 \pm 2.48$ & $>0.05$ \\
\hline At 5 min (Post-intubation) & $64.27 \pm 1.8$ & $75.73 \pm 1.32$ & $<0.001$ \\
\hline At 10 min & $79.27 \pm 7.84$ & $76.67 \pm 4.03$ & 0.007 \\
\hline At 15 min & $78.40 \pm 1.96$ & $85.20 \pm 2.78$ & 0.001 \\
\hline At 20 min & $79.60 \pm 1.64$ & $87.20 \pm 2.34$ & 0.001 \\
\hline At 35 min & $88.28 \pm 0.8$ & $89.23 \pm 2.4$ & 0.001 \\
\hline At 50 min & $89.89 \pm 4.72$ & $87.4 \pm 1.2$ & $>0.05$ \\
\hline At 65 min & $89.22 \pm 1.37$ & $91.22 \pm 5.80$ & $>0.05$ \\
\hline At 80 min (Post-extubation) & $94.9 \pm 2.4$ & $90.09 \pm 4.18$ & $>0.05$ \\
\hline
\end{tabular}

- Heart rate: There was a statistically significant decrease immediately after induction of general anesthesia, at $35^{\text {th }}$ minute, $50^{\text {th }}$ minute and $65^{\text {th }}$ minute in both groups (A and $\mathrm{B}$ ) with more decrease in group B than group $\mathrm{A}$. while, there was a statistically significant increase at $5^{\text {th }}$ minute (post-intubation), $10^{\text {th }}$ minute, $15^{\text {th }}$ minute, $20^{\text {th }}$ minute and $80^{\text {th }}$ minute (postextubation) in both studied groups with more increase in group A than group B. Also, there was a statistically significant increase at $5^{\text {th }}$ minute (post-intubation), $10^{\text {th }}$ minute, $15^{\text {th }}$ minute, $20^{\text {th }}$ minute in both studied groups (A and B) when compared with immediately after induction of general anesthesia in the same group A or B. Also, there was a statistically significant increase at $80^{\text {th }}$ minute in both studied groups (A and B) when compared with $65^{\text {th }}$ minute with more increase in group A than group B (Table 5). 
Table (5): Heart rate among studied populations at different points of time (beat/minute)

\begin{tabular}{|c|c|c|c|}
\hline \multirow{2}{*}{ Garameters } & A & B & \multirow{2}{*}{ P value } \\
\cline { 2 - 3 } & Mean \pm SD & Mean \pm SD & \\
\hline 1 & $81.8 \pm 1.87$ & $74.47 \pm 2.37$ & $<0.001$ \\
\hline At 5 min (Post-intubation) & $72.23 \pm 1.5$ & $53.73 \pm 3.39$ & $<0.001$ \\
\hline At 10 min & $92.1 \pm 5.87$ & $83.8 \pm 3.56$ & $<0.001$ \\
\hline At 15 min & $97.6 \pm 7.73$ & $88.4 \pm 4.56$ & $<0.001$ \\
\hline At 20 min & $91.8 \pm 5.39$ & $86.0 \pm 1.2$ & $<0.001$ \\
\hline At 35 min & $85.7 \pm 7.22$ & $73.6 \pm 5.98$ & $<0.001$ \\
\hline At 50 min & $77.6 \pm 2.31$ & $70.93 \pm 0.97$ & $<0.001$ \\
\hline At 65 min & $78.27 \pm 3.51$ & $71.20 \pm 6.48$ & $<0.001$ \\
\hline At 80 min (Post-extubation) & $76.93 \pm 5.36$ & $73.27 \pm 2.55$ & $<0.03$ \\
\hline
\end{tabular}

III. Adverse side effects: There was no significant difference between both groups. In group A, two patients $(13.4 \%)$ reported nausea and/or vomiting; while in group $\mathrm{B}$, one patient $(6.7 \%)$ reported nausea and/or vomiting (Table 6).

Table (6): Comparison between studied groups as regard to post-operative adverse effects

\begin{tabular}{|c|c|c|c|c|c|}
\hline \multirow{2}{*}{ Parameter Groups } & \multicolumn{2}{|c|}{ A } & \multicolumn{2}{|c|}{ B } & \multirow{2}{*}{ P value } \\
\cline { 2 - 5 } & $\mathrm{n}$ & $\%$ & $\mathrm{n}$ & $\%$ & \\
\hline Nausea and/or vomiting & 2 & 13.4 & 1 & 6.7 & $>0.05$ \\
\hline
\end{tabular}

IV. Postoperative Pain assessment: difference between both groups There was no statistically significant postoperatively (Table 7).

Table (7): Comparison between studied groups as regard to Visual Analogue (VAS) Score postoperatively

\begin{tabular}{|c|c|c|c|c|c|}
\hline \multirow{2}{*}{ Groups } & \multicolumn{2}{|c|}{ A } & \multicolumn{2}{c|}{ B } & \multirow{2}{*}{ P value } \\
\cline { 2 - 5 } Parameters & Mean & S. D & Mean & S. D & \\
\hline At 1 h. & 0.43 & 0.50 & 0.56 & 0.50 & $>0.05$ \\
\hline At2h. & 0.53 & 0.50 & 0.73 & 0.63 & $>0.05$ \\
\hline At4h. & 2.36 & 0.61 & 2.26 & 0.58 & $>0.05$ \\
\hline At8h. & 2.26 & 0.58 & 2.43 & 0.72 & $>0.05$ \\
\hline At 16h. & 2.33 & 0.75 & 2.43 & 0.85 & $>0.05$ \\
\hline At 20h. & 2.40 & 0.62 & 2.56 & 0.77 & $>0.05$ \\
\hline At 24h. & 2.20 & 0.40 & 2.16 & 0.69 & $>0.05$ \\
\hline
\end{tabular}

V. Postoperative discharge criteria: Patients of both groups (A and B) were discharged according to a Mayo Modified Discharge Scoring System $\geq 10$ was achieved in two consecutive measurements without any significant difference. 


\section{DISCUSSION}

Hypertension is commonly associated with increased hemodynamic instability in the perioperative period and this is associated with increased risk of myocardial injury Robert et al. (2008).

The response to anesthetic induction and airway manipulation in the presence of cardiovascular disease and antihypertensive therapy has not been adequately investigated. Diseases of the cardiovascular system, like hypertension, additionally affect the normal physiological response of the body to anesthesia induction and intubation. The changes associated with laryngoscopy and intubation can be more severe and more dangerous in hypertensive patients. In addition, this response is complicated by the anti-hypertensive therapy (Samad et al. 2008).

Blood pressure changes (systolic, diastolic and mean blood pressure) immediately after induction period showed a statistically significant decrease immediately after induction of general anesthesia in both groups (A and B) with more decrease in group A than group B. These results were consistent with (Samad et al., 2008) who studied the prevalence and severity of hypotension after induction of anesthesia in hypertensive patients treated with either beta blockers (BB) and angiotensin converting enzyme inhibitors (ACEI). They stated that hypotension was seen in all patients in the patients in BB group and in ACEI group. The hypotension was most severe and refractory in the ACEI group. They also, reported that beta blockers have little effect on normal heart in a resting patient, but they decrease heart and myocardial contractility when sympathetic activity is decreased. Anesthesia imposes additional myocardial depression in beta blocked patients but this is well tolerated as anesthesia is commonly accompanied by vasodilatation that unloads ventricles and facilitates forward flow. This fall in BP was not accompanied by myocardial ischemia. Also, it has been reported that, hypotension during induction is more noticeable in patients continuing ACE inhibitor therapy up until the time of surgery.

During the period from $5^{\text {th }}$ minute after induction till the $35^{\text {th }}$ minute and the $80^{\text {th }}$ minute, there was a statistically significant increase in blood pressure at 5 minutes (post-intubation) in both studied groups with more increase in group A than group $\mathrm{B}$, and also, at 80 minutes (postextubation) in group A only when compared with group B. This period corresponded to the period after laryngoscopy, tracheal intubation, and post-extubation of endotracheal tube which was a period of hemodynamic instability. Also, there was a statistically significant decrease in group $\mathrm{A}$ when compared with group B at $10 \mathrm{~m}, 15 \mathrm{~m}$, $20 \mathrm{~m}, 35 \mathrm{~m}$ after endo-tracheal intubation. Thus, hypertensive patients in group A had more decrease in blood pressure immediately after induction of general anesthesia and more increase in blood pressure post-intubation (at $5^{\text {th }}$ minute) and post-extubation (at $80^{\text {th }}$ minute). After that group A had more decrease in blood pressure at $\left(10^{\text {th }}\right.$ minute, $15^{\text {th }}$ minute, $20^{\text {th }}$ minute and $35^{\text {th }}$ minute) when compared with group B subsequently, more hemodynamic instability than group B. 
These results were in agreement with Samad et al. (2008) who reported that, regardless of the level of preoperative blood pressure control, many patients with hypertension display an accentuated hypotensive response to induction of anesthesia, followed by an exaggerated hypertensive response and tachycardia to laryngoscopy and intubation .

In addition, Weisenberg et al. (2010), reported a greater incidence of hypotensive episodes after induction of anesthesia in patients treated with ACEI in whom therapy was continued up to the day of surgery.

These results were in agreement with Hani and Academic. (2014) who reported that angiotensin converting enzyme inhibitors (ACEIs), as Captopril, enalapril, can blunt the compensatory activation of the renin-angiotensin system during surgery and result in prolonged hypotension especially in the first 30 minutes of operation.

Foex and Sear (2010) studied the relationship between ?-blockade and anesthesia, and reported that ?-blockade is compatible with anesthesia and offered the advantage of hemodynamic stability at the time of sympathetic stimulation in addition to reducing the risk of myocardial ischemia and ventricular arrhythmias as confirmed by several studies.

In addition, these results coincided with Bangalore et al. (2008) who reported that, $\beta$ blockers have been promoted as potentially improving cardiovascular outcomes perioperatively by extrapolation of the cardio-protective properties from patients with established coronary artery disease.
However, Blessberger et al. (2014) studied the effect of BB on patients under general anesthesia and concluded that any type of surgery is associated with an increased stress response, which can make the body vulnerable to unwanted outcomes. These outcomes may range from death to a heart attack and rhythm disturbances to heart failure, stroke. Betablockers are drugs that attenuate this stress response, which results in slowing down of heart rate and a fall in blood pressure. Whereas on the one hand, these effects are desirable to fight the stress response, the same effects if pronounced may cause very low blood pressure, a very low pulse and ultimately stroke or death.

Various attempts have been made to suppress the pressor response of intubation and extubation. The pharmacological methods are aimed at efferent, afferent, or both limbs of response e.g. volatile inhalational agents, lignocaine, opioids, sodium nitroprusside, nitroglycerine, calcium channel blockers, and beta-adrenergic blockers (Singh and Antognini, 2011).

As regard to heart rate, there was a statistically significant decrease immediately after induction of general anesthesia, at $35^{\text {th }}$ minute, $50^{\text {th }}$ minute and $65^{\text {th }}$ minute in both groups (A and B) with more decrease in group B than group A. while, there is statistically significant increase at $5^{\text {th }}$ minute (post-intubation), $10^{\text {th }}$ minute, $15^{\text {th }}$ minute, $20^{\text {th }}$ minute and $80^{\text {th }}$ minute (post-extubation) in both studied groups with more increase in group A than group B.

Also, there was a statistically significant increase at $5^{\text {th }}$ minute (postintubation), $10^{\text {th }}$ minute, $15^{\text {th }}$ minute, $20^{\text {th }}$ 
minute in both studied groups (A and B) when compared with immediately after induction of general anesthesia in the same group A or B. Also, there was a statistically significant increase at $80^{\text {th }}$ minute in both studied groups (A and B) when compared with $65^{\text {th }}$ minute with more increase in group A than group B.

These results coincided with Foex and Sear. (2010) who found that there was a reduced heart rate response in the $\beta$ blocked group of patients to laryngoscopy and intubation when comparing ACEI and BB with other antihypertensive drugs .

Beta blockers have blunted the hemodynamic response to laryngoscopy and intubation in normotensive as well as hypertensive patients (Samad et al., 2008).

(Beta blockers were associated with a significant perioperative bradycardia (Bangalore et al., 2008 and Wijeysundera et al., 2014).

\section{CONCLUSION}

Bisoprolol as antihypertensive drug provided more perioperative hemodynamic stability all over the operation than Enalapril especially at the periods of stressful events as postinduction and emergence from anesthesia.

\section{REFERENCES}

1. Athanasios J, Manolis, Serap E, Claudio. and Borghi. (2010): Perioperative screening and management of hypertensive patients: European Society of Hypertension Scientific Newsletter. Update on Hypertension Management, 11: No. 47.

2. Bangalore S, Wetterslev J, Pranesh S, Sawhney S, Gluud $C$ and Messerli FH. (2008): Perioperative $\beta$ blockers in patients having non-cardiac surgery: a meta-analysis. The Lancet, 372(9654): 1962-1976.
3. Barodka V, Nyhan D and Berkowitz D. (2012): Perioperative use of angiotensinconverting enzyme inhibitors. Circulation, 126(3):249-251.

4. Beyer K, Taffé P, Halfon P, Pittet, V, Pichard S, Haller $G$ and Burnand B. (2009): Hypertension and intra-operative incidents: a multicenter study of 125000 surgical procedures in Swiss hospitals. Anesthesia, 64(5): 494-502.

5. Blessberger H, Kammler J, Domanovits H, Schlager O Wildner B, Azar D and Steinwender C. (2014): Perioperative beta-blockers for preventing surgery-related mortality and morbidity. Cochrane Database of Systematic Reviews (9).

6. Brokelman R. B., Haverkamp D. and van Loon C. (2012): The validation of the visual analogue scale for patient satisfaction after total hip arthroplasty. European Orthopaedics and Traumatology, 3(2): 101-105.

7. Chung F, Ritchie E, and Su J. (1997): Postoperative pain in ambulatory surgery. Anesthesia \& Analgesia, 85(4): 808-816.

8. Foex P and Sear JW (2010): Challenges of ?blockade in surgical patients. Anesthesiology, 113:767-771.

9. Frishman WH and Saunders E. (2011): Adrenergic blockers. Journal of Clinical Hypertension, 13(9): 649-653.

10. Hani, C and Academic B. (2014): Hypertension and Anaesthesia, University of Witwatersrand, African Family Practice Journal, 56(2): 5-9.

11. Jankowski CJ, Hebl JR and Stuart MJ. (2003): A comparison of psoas compartment block and spinal and general anesthesia for outpatient knee arthroscopy. Anesth Analg., 97:1003-9.

12. Robert J, Heyka and Vermeulen M. (2008): Evaluation and Management of Hypertension in the Intensive Care Unit: Irwin, Richard S.; Rippe, James M. (editors). Cardiovascular Problems and Coronary Care: Irwin and Rippe's Intensive Care Medicine. 6th Edition, 3; 37: 392-99. 
13. Samad K, Khan F and Azam I. (2008): Hemodynamic effects of anesthetic induction in patients treated with beta and calcium channel blockers. Middle East Journal of Anesthesiology, 19(5): 1111-1128.

14. Singh A and Antognini JF (2011): Perioperative hypotension and myocardial ischemia: Diagnostic and therapeutic approaches. Ann Card Anaesth., 14: 127-132.

15. Soto-Ruiz, K. M., varoock, W. F. and Varon, J. (2011): Perioperative hypertension: Diagnosis and Treatment. Netherlands Journal of Critical Care, 15(3): 143-148.

16. Weisenberg M, Sessler DI, Tavdi M, Gleb M, Ezri T, Dalton JE and Zimlichmann R. (2010): Dose-dependent hemodynamic effects of propofol induction following brotizolam premedication in hypertensive patients taking angiotensin-converting enzyme inhibitors. Journal of Clinical Anesthesia, 22(3): 190-195.

17. Wijeysundera DN, Duncan D, Nkonde-Price C, Virani S Washam JB, Fleischmann KE and Shen WK. (2014): Perioperative beta blockade in noncardiac surgery: A systematic review for the ACC/AHA guideline on perioperative cardiovascular evaluation and management of patients undergoing noncardiac surgery. Circulation, 130(24): 2246-2264. 


\section{تأثير البيسوبرولول مقابل الاينالابريل على الديناميكية الدموية تحت تأثير المخدر العام الايري}

توفيق محمد نور الدين ، سعد الدين محمود الخطيب ، عبد الله منصور أحمد ، يسري محمد عبد السلام** ، أيمن حلمي محمود*

\section{أقسام التخديز والعناية المركزة بطب الأزهر بالقاهره ودمياط*}

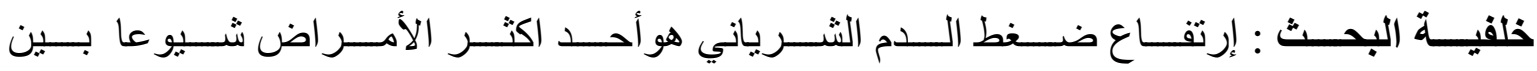

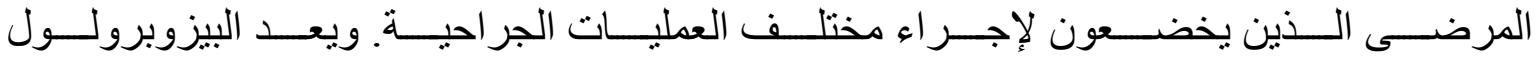

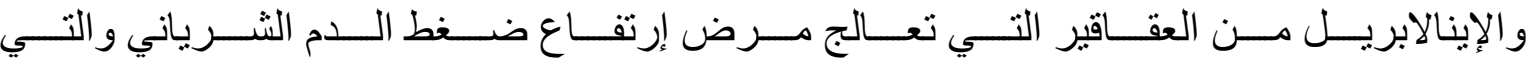

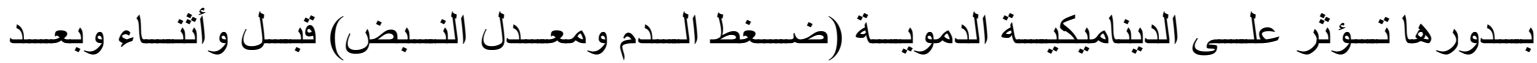
العمليات الجر احية بأساليب مختلفة.

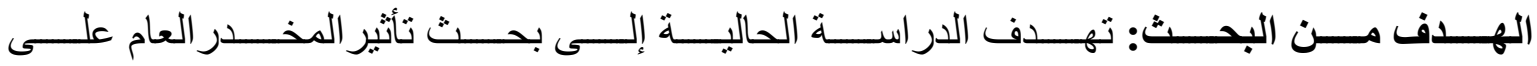

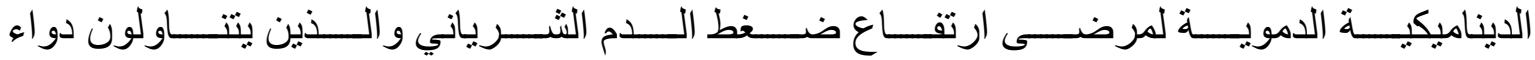

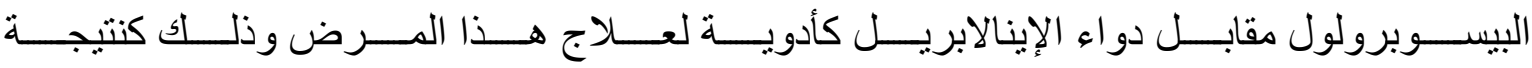

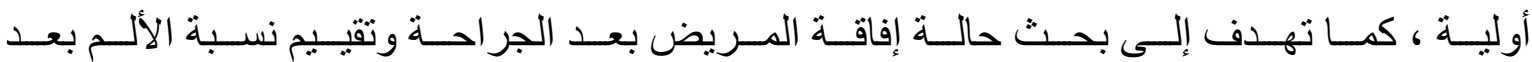

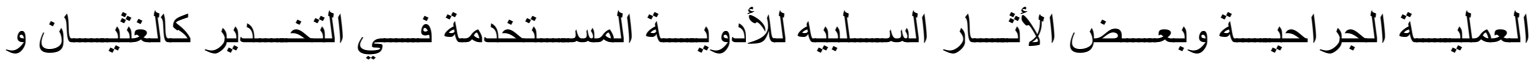
القئ كنتيجة تنانوية.

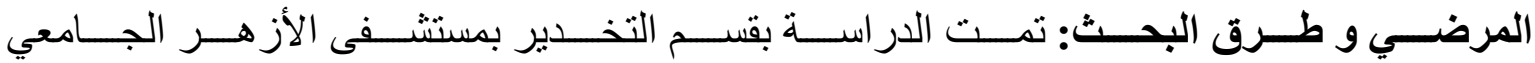

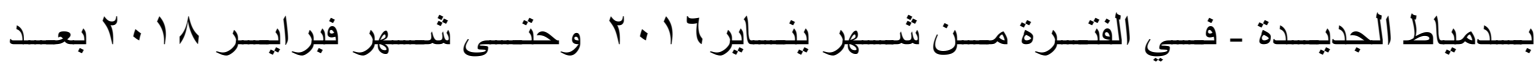

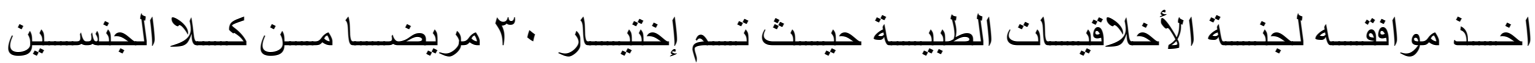

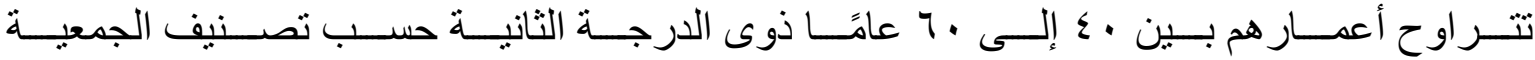

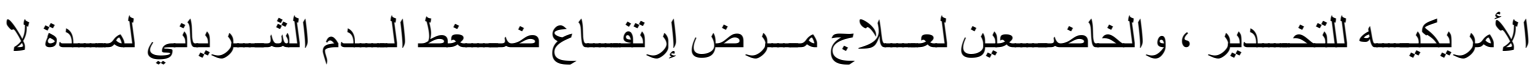

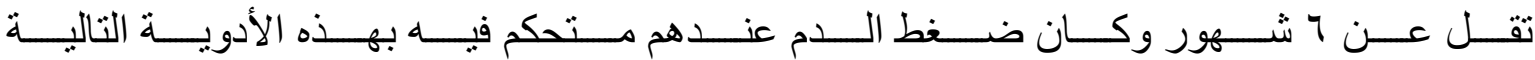

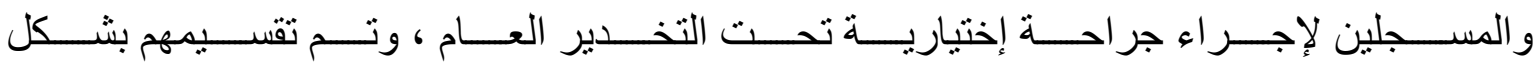
عشو ائي إلي مجمو عتين منساو يتين : المجموعــة الأولــى (أ): خمســة عثــر مريضـــــــــــاولون مثبطـــات الإنــزيم المحــول للأنجيوتنسين (الإينالابريل · (مج). 


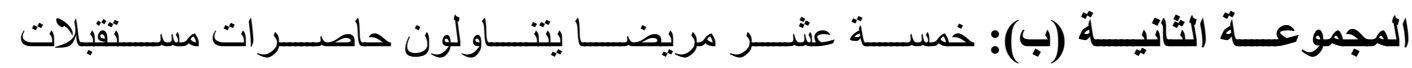
البيتا (البيسوبرولول 0 مجم).

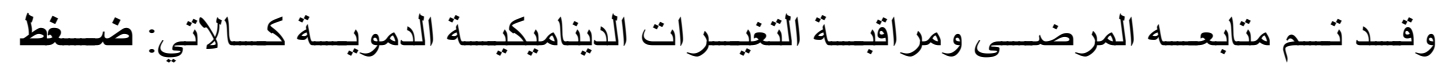

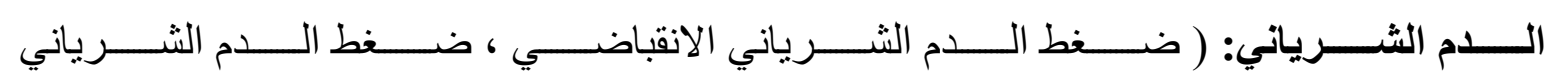

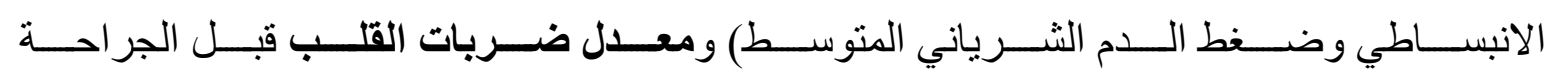

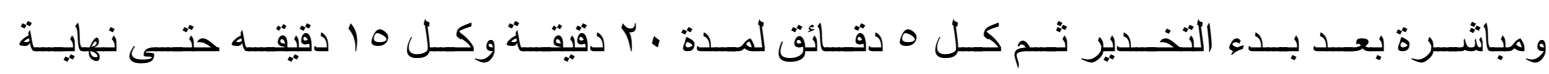

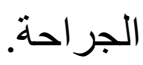

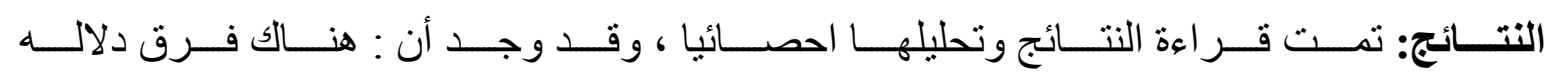

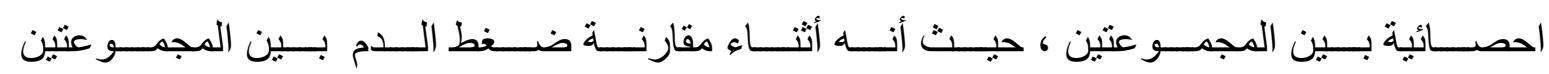

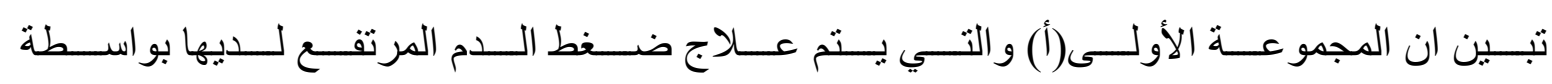

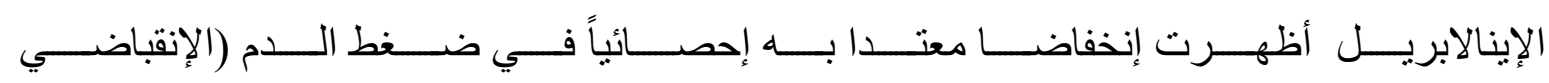

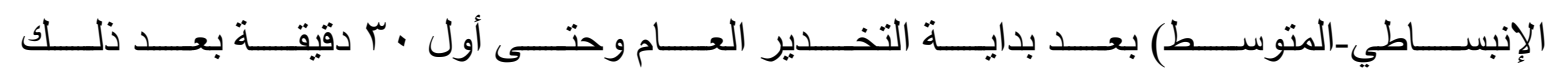

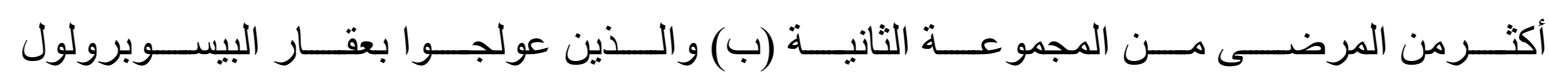

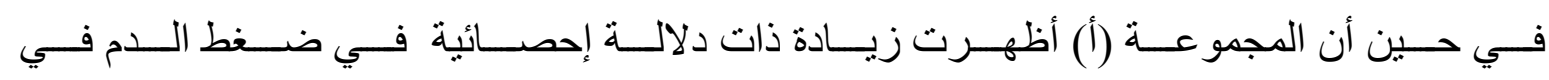

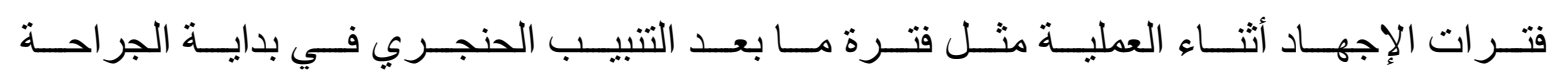

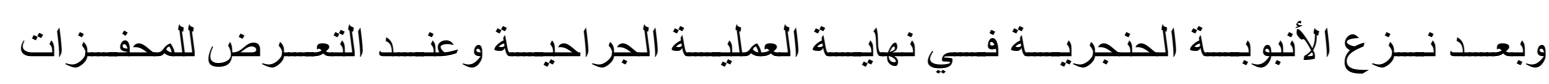

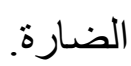

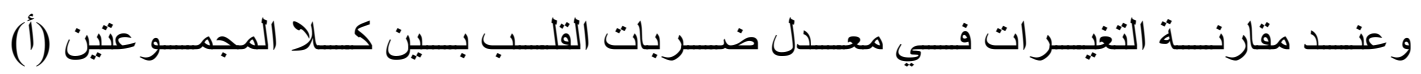

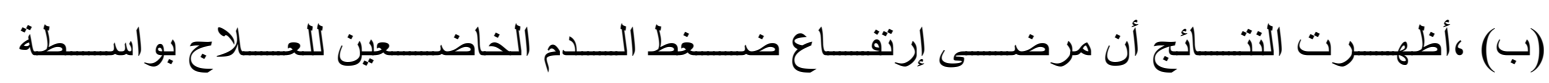

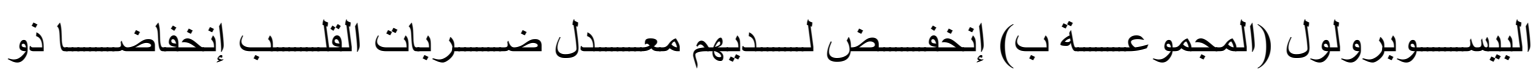

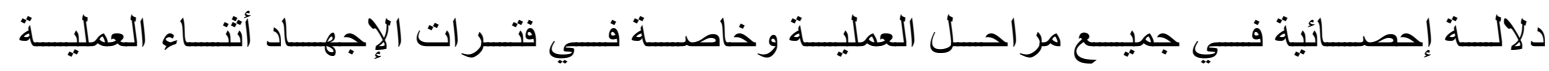

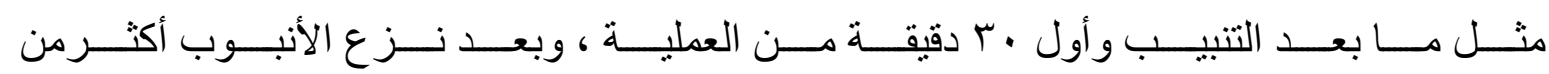
المرضى الخاضعين للعلاج بو اسطة الإينالابريل (المجموعة أ).

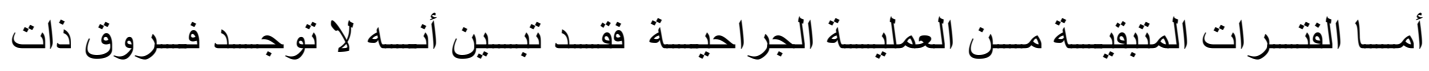
دلالة إحصائية بين المجمو عتين فيما يتعلق بضغط الدم ومعدل ضربات القلب. 


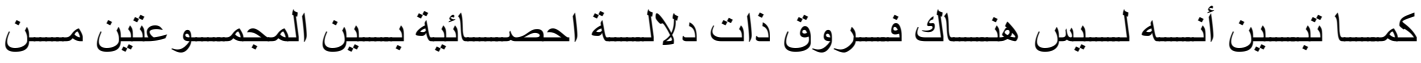

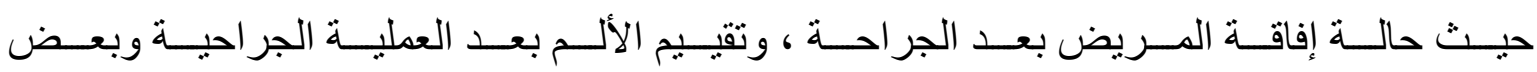
الأثنار السلبية للأدوية المستخدمة في التخدير كالغنيان و القئ.

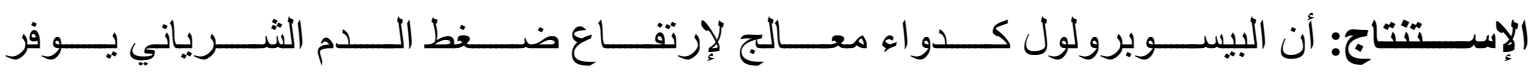

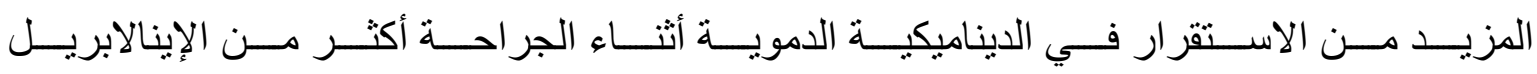

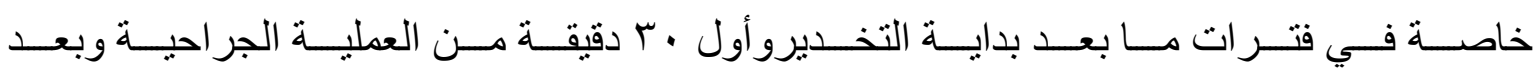
إز الة الأنبوب الرغامي و الإفاقة من التخدير الكلي. 